えることによって，好意的な印象を与えられることが確認された。

\title{
1P1-H-39 人間とロボットの共創動作システムに関する研究
}

一握手動作における人間の動特性の解析一

○大野 慎吾 (東海大), 稻葉 毅 (東海大)

A Study on Human-Robot Cocreative Motion System

- Analysis of a Human Arm Dynamics in Handshake Motions -

OOhno.S (Tokai Univ.), Inaba.T (Tokai Univ.)

本研究では, 人間とロボットが機械力学的に互いに影響し合い, 結果としてある動作が発生するシステム (人間一ロボット共創動 作システム) を取り扱う。本報告ではその基礎検討の例題として握手動作を取り上げる．握手動作は，ある周期運動が相手との間 に自然に共創されるものと考えられる。すわなち，ロボット側は人間との動作を通じて自律的に運動の軌道生成し，さらに人間側 から感じる柔らかさといったインピーダンス調整をも行う必要がある，そこで，本研究ではロボットとの握手動作を人間とロボッ トからなる閉ループ系 (人間一機械制御系) とみなし，握手動作時における人間の動特性と閉ループ特性について検討する．その結 果，人間とロボットからなる閉ループ系に共振周波数が存在し，それがロボットの動特性によって变化することや，人間に自然な 握手動作を行わせた場合，その周波数は系の共振周波数と関連性があることなどがわかった.

\section{จデジタルヒューマン 2}

\section{P1-H-45＼cjkstart指の屈曲・伸展動作を表現する曲率変化モデルの提案}

○豊田 平司郎 (慶大), 森田 寿郎 (慶大)

\section{A Curvature Model for Extension and Flexion of Human Fingers}

OToyoda.H (Keio Univ.), Morita.T (Keio Univ.)

本研究では，ヒトの指の基本動作を関数的に表すモデルを提案した。指の基本動作は，MP 関節屈曲に追従する PIP 関節およ び DIP 関節の屈曲変位により生み出される指列パターンである。その指列と屈曲に伴う指列の変化を関数表現するために，皮虔 包絡線に注目して計測を行ったままず，脱力した状態での指の皮膚包絡線を計測した結果，放物線および楕円の弧で十分に表現で きた．次に，MP関節を自然に屈曲させたときの皮膚包絡線を計測した結果，放物線では屈曲度が大きい時に対応しなかった。一 方，楕円の弧を用いた場合，MP 関節屈曲度が大きい場合でも皮盧包絡線を表せた．また，楕円の弧で皮膚包絡線を表した場合， MP 関節の屈曲度に対して, 楕円の弧の形状を決める 2 つのパラメータは一意に決まる関数が存在することがわかった.

\section{P1-H-46＼cjkstart筋骨格モデルに基づく人間の体性感覚情報の高速計算}

藤田 悠介 (東大), ○山根 克 (東大), 大武 美保子 (東大), 中村 仁彦 (東大)

Efficient Computation of Somatosensory Information Based on Musculoskeletal Human Model

Fujita.F (Univ. of Tokyo), OYamane.K (Univ. of Tokyo), Otake.M (Univ. of Tokyo), Nakamura.N (Univ. of Tokyo)

本論文では，モーションキャプチャデータと筋電位・床反力の計測データを用いて，ヒトの体性感覚情報を推定する方法につい て述べる，ヒトの筋骨格モデルは一般に染長駆動系であるため，ある運動を行うのに必要な筋張力が一意には決まらない．また， 2 つ以上のリンクが接触している場合には不整定問題となり，それぞれのリンクにかかる接触力が決まらない，そこで，筋骨格モデ ルの逆動力学計算を最適化問題として定式化し, 評価関数に筋電位・床反力の計測データを反映させることで, 力学的にも生理学 的にも妥当な筋張力の計算を可能にする. 本手法を用いて, 特定のタスクに対する標準的な筋張力の配分をデータベース化するこ とができれば，筋電位・床反力情報がない場合でも体性感覚を推定できるようになる可能性がある.

\section{P1-H-47＼cjkstart多重目標軌道間遷移による二足歩行のバランス制御}

○宮腰 清一 (産総研), Cheng Gordon(ATR)

Balancing control of biped walking via switching of multiple objective trajectories OMiyakoshi.S (AIST), Cheng.G (ATR)

二次元コンパス状二足歩行システムのための簡明なバランス制御器を提案する.この制御器は, 単脚支持期において, 支持脚の 角度・角速度を参照して，適切な着地点に到達するような多数の軌道閒を遷移する事により，動的にバランスを維持する。これ等 の軌道は, 部分的に駆動されるような (劣駆動の) モデルを用いたシミュレーションにより求められる. シミュレーションにおい て, この制御器は, 外乱の下でもバランスを維持する事が可能だった。

\section{P1-H-48＼cjkstart自然な歩行の解析のための六軸力計測フットウエア}

○高橋 洋平 (東理大), 加賀美 聡 (産総研), 江原 義弘 (帝京大), 持丸 正明 (産総研), 溝口 博 (東 理大)

Six-axis Force Sensing Footwear for Natural Walking Analysis

OTakahashi.Y (Tokyo univ. of Science), Kagami.S (AIST, JST), Ehara.Y (Teikyo univ.), Mochimaru.M (AIST, JST), Mizoguchi.H (Tokyo univ. of Science) 